\title{
The heterogeneous landscape of innovation in female led-businesses - cross-country comparisons
}

\author{
Adina FILCULESCU \\ The Bucharest University of Economic Studies, Romania \\ adinafilculescu@gmail.com
}

\begin{abstract}
Female led-businesses are nowadays regarded as a vehicle for worldwide economic and social wellbeing. Seen as a mechanism for better social inclusion, empowerment, wide institutional change and local economic development, female entrepreneurship has been the focus of many scholarly pursuits. However, one field in which the interest in female-led businesses has been somewhat overlooked and overshadowed by other topics is the field of innovation studies. There are various national and international programs meant to increase the level of innovativeness of female-led businesses and there are reports presenting somewhat contradictory results in which women business owners are portrayed either as more innovative or at a disadvantage when it comes to the resources needed for innovation in comparison to their male counterparts. Thus, this study seeks to disentangle the various aspects which affect the landscape of innovation in female led-businesses by focusing on the way in which the national contexts creates opportunities or barriers for innovation. Based on the qualitative data provided by the GEM 2012 Adult Population Survey, we show that, in the case of the six countries included in the sample, the landscape is highly heterogeneous and that macrolevel indicators such as percentage of female entrepreneurs, public support for high growth female entrepreneurship and gender equality are not capable of fully explaining the innovation behavior of female-led businesses. The results presented here contribute to advancing the research on innovation and female entrepreneurship by opening up new avenues for research which will renounce the paradigm of an ideal type of female-led business, and start to seriously take into consideration the heterogeneity of these businesses and of the landscapes in which they operate.
\end{abstract}

Keywords: female entrepreneurship, innovation, business women, country comparison, women entrepreneurs.

Please cite this article as follows: Filculescu, A. (2016), "The heterogeneous landscape of innovation in female-led businesses - cross-country comparisons", Management \& Marketing. Challenges for the Knowledge Society, Vol. 11, No. 4, pp. 610-623. DOI: 10.1515/mmcks-20160019.

\section{Introduction}

Today women entrepreneurs are hailed as an unstoppable force that will generate worldwide economic and social wellbeing. Female entrepreneurship is seen as a mechanism for social inclusion, empowerment, institutional change and local economic development (Calás et al., 2009). As women's entrepreneurship gains momentum, fact shown by global reports such as the Global Entrepreneurship 2014 Women's Report which states that women have created 7\% more business since 2012 and that the gender gap in entrepreneurial activity has decreased by $6 \%$, scholars and public authorities are demonstrating an increased interest in gauging the impact that these new economic activities are having on the local and national economies. 
Although there are differences between countries and regions, on average, female-led firms are consistently demonstrating a more innovative behavior than male-led firms. For example, in the developed world women entrepreneurs are either more prone to introduce innovative products and services to the market than men entrepreneurs, or exhibit similar rates of innovation (Vanderbrug, 2013). However, in developing countries, there exists a gap in the level of market innovation of women entrepreneurs which, by most accounts, is due to a lack of access to basic resources necessary for innovation such as skilled workforce, financial resources and education (Ighomereho et al., 2013).

These realities have spurred an interest from public policy makers and international organizations which have created special policies and programs meant to foster female entrepreneurs' innovative behavior. A recent example is the Global Coalition of Young Women Entrepreneurs, a global UN program launched in 2016 which will promote young women's innovation and entrepreneurship through partnerships with young women leaders, entrepreneurs, philanthropists, academic researchers, and businesses. At the level of the European Union, there is the EU Prize for Women Innovators which is awarded to female entrepreneurs who founded successful companies based on research supported by EU funding. There are also national level initiatives that are meant to increase the access to resources necessary for innovation for female entrepreneurs, such as the US InnovateHER Business Challenge which is designed to give funding to female led-firms with innovative products and services. However, there is still more room for improvement in terms of public and private support offered to female entrepreneurs. A recent report from the World Bank showed that the evidence of the impact of past programs meant to foster entrepreneurship and innovation among women is inconsistent (Cirera and Qasim, 2014). Moreover, scholars have argued that the introduction of new and narrow targeted programs is not as efficient as the redesign of existing entrepreneurial support programs using a gender-inclusive paradigm (Watkins et al., 2015).

In order for these changes to take shape, there needs to be a more prominent contribution of scholars studying the fields and entrepreneurship and innovation, which until now have looked at gender only as a marginal factor. Thus, this article presents a summary of the existent literature on female entrepreneurship and innovation and identifies the main trends and gaps. After that, we present our research on female entrepreneurship and innovation based on data from GEM's Adult Population Survey of 2012 and we conclude with several suggestions for the improvement of the studies of innovation in female-led businesses.

\section{Women entrepreneurship and innovation}

Currently there is an abundance of resources of information regarding female entrepreneurs and their businesses, entrepreneurship and innovation and also on the way in which innovation (especially social innovation) has improved the lives of women in general, but there are still gaps in our knowledge regarding the way in which these three domains intersect: entrepreneurship, innovation and gender (Filculescu and Cantaragiu, 2012). Until now, the literature on women entrepreneurship has mostly focused on the barriers which impede women from 
starting and growing their businesses, placing an emphasis on survival rather than on growth through innovation. On the other hand, the interest in studying innovation has been significantly driven by the previous economic crisis which has turned the focus of scholars and public authorities to the way in which innovation increases competitiveness and ensures sustainability (Belghiti-Mahut et al., 2016), but innovation studies have not been particularly interested in the actors who are involved in the innovation process (Fagerberg et al., 2005). Thus, the innovator with his or her particularities have been rendered invisible in the innovation literature and as a result, the gender dimension has been marginalized as well, being taken into consideration mostly in terms of the inclusion/exclusion of women in research and development (Ranga and Etzkowitz, 2010).

Innovation studies rarely discuss the ways in which women entrepreneurs. innovation habits differ from those of their male counterparts and most scholars agree that there is a stringent need for a better understanding of the challenges faced by women entrepreneurs if countries are going to take full advantage of the power of female entrepreneurship. The primary concern of the various studies that discuss innovation and female entrepreneurship is to compare the level of innovativeness between female and male-owned firms and then to see if the types of innovation differ. However, in terms of the level of innovation there is no clear pattern discernable from the results of the studies available until now, mostly because they have used various measures of innovation.

When innovation is measured using soft indicators such as the attitude of business owners towards innovative behaviors and innovation in general, women are found to be more supportive of new ideas, products, processes and creative methods, demonstrating a greater inclination towards experimentation and risk taking (Jensen, 2014; Runyan et al. 2006; Serviere-Munoz and Saran, 2012) and to consider innovation as an important strategic success factor in a higher degree than men (Zapalska, 1997). In a study of social enterprises from several countries, Huysentruyt (2014) identified the same patterns of innovation in relation to the introduction of new or improved processes, services or products and expenditure for innovation even though women spent less on process innovation, but also found that women were more likely to plan to enter new markets and encourage radical innovation, most probably motivated by the need to respond to competitive pressures. In a study using the 5th wave of the Business Environment and Enterprise Performance Survey (BEEPS) conducted in 2012-2013 which included data on 5254 SMEs from 30 European and East Asia countries, Akulava (2015) identified a small, but positive effect of having a female owner on the propensity of the firm to implement a new product or service and to introduce a new business process or marketing strategy. Other studies found no difference between male and female business owners when taking into consideration the introduction of new products, new organizational structures and other forms of innovation (Kalleberg and Leicht, 2001).

However, when innovation is measured using hard indicators such as patenting activity and research and development expenses, male-owned firms outperform female-owned firms. A study performed by Marvel and Lee (2011) on a sample of young Korean firms showed that male entrepreneurs submitted a higher number of intellectual property rights claims as a result of their innovative activities, and that 
male-owned firms allocated larger budgets for research and development and had larges human resources dedicated to $R \& D$. This could be explained by the fact that women entrepreneurs regard the possibility of obtaining intellectual property rights as much more difficult than men entrepreneurs (Bobera and Leković, 2013). These results mirror the situation encountered in the science and technology field in general, because here women are said to suffer from the Athena complex and the fact that their numbers decrease along the career stages is explained by the leaky pipeline effect which is portrayed as the decrease in the number of female scientists along the stages of a normal career, including commercialization of their research results (Polkowska, 2013) due to gender related barriers.

The fact that the research results vary so widely can be accounted for if we consider that gender, entrepreneurship and innovation are contextually embedded and that there are several factors such as social norms and institutional support which influence women entrepreneurship and innovation, hindering direct comparisons of research results (Ahl, 2006; Hughes et al., 2012). These factors have only recently started to be included in the research design (Blake and Hanson, 2005), but there are still only a couple of studies of women entrepreneurship and innovation which adopt a comparative strategy that also takes into account environmental factors. Moreover, Sullivan and Meek (2012) state that the literature on the gendering of innovation is too reliant on case studies of individual entrepreneurs rather than on large samples of firm owners and that this is not conducive to theory building and does not help decision makers in creating better public policies on innovation.

\section{Research methodology \\ Research questions}

The research presented here set out to test the following hypotheses which measured the level of country effect on the innovation behavior of female entrepreneurs:

RH1: There are differences between female entrepreneurs generated by country effects in terms of the level of customer product innovation.

RH2: There are differences between female entrepreneurs generated by country effects in terms of the level of industry product innovation.

RH3: There are differences between female entrepreneurs generated by country effects in terms of the level of operations innovation.

This set of hypotheses was based on the fact that the literature on women entrepreneurship has shown that contextual factors can have a higher influence on the way in which female entrepreneurship is enacted than individual level factors (Yousafzai et al., 2015). Studies comparing women entrepreneurs in developed and developing countries have shown that there are differences in entrepreneurial behavior due to lack of market information, lack of external support systems, local social norms and lack of access to new technology (UNCTAD, 2015). However, there are also studies which argue that the level of gender equality in a certain country does not have an effect on the level of women entrepreneurship (Sarfaraz et al., 2014). Thus, it is generally accepted that contextual factors related to access to infrastructure, new technologies and a healthy business and social environment have a direct impact on the opportunities for innovation of women entrepreneurs, but 
MMCKS

614

there are still questions regarding the way in which other contextual factors such as social norms and policy support impact female entrepreneur's behavior when comparing countries with a similar level of economic development.

\section{Data gathering}

This research is based on the data contained in the GEM 2012 Adult Population Survey - Individual Level Data obtained from www.gemconsortium.org. This database has been used in the past by various researchers in order to study entrepreneurship in general (Castaño et al., 2015; Barazandeh et al., 2015; Mrożewski and Kratzer, 2016), women entrepreneurship (e.g. Verheul et al., 2005; Minniti and Arenius, 2003) and even women entrepreneurship and innovation (Manasi et al., 2015; Jiarong and Shouming, 2016) as it allows for country-based comparisons.

In order to test our hypotheses, we chose a set of six countries displaying different levels of gender equality, support mechanisms for high growth female entrepreneurship and different levels of overall female entrepreneurship (see Table 1). These are all factors which have been previously discussed in the literature regarding female entrepreneurship and innovation. Gender equality has shown mixed results in what regards its influence on female entrepreneurship (Sarfaraz et al., 2014; Kobeisi, 2010), whereas the support for high-growth female entrepreneurship has been deemed extremely important for the level of innovation of female-led businesses (Terjesen et al., 2015; Terjesen, 2016). We also included the level of female entrepreneurship in the country because female entrepreneurship has been shown to have a multiplying effect and to breed female entrepreneurship (Pérez-Pérez and Avilés-Hernández, 2016) and thus it could also have an impact on the level of innovation in female-led businesses.

Table 1. Description of countries selected for research

\begin{tabular}{|l|c|c|c|c|}
\hline Country & $\begin{array}{c}\text { \% of female } \\
\text { entrepreneurs } \\
\text { (2012) }\end{array}$ & $\begin{array}{c}\text { Female } \\
\text { Entrepreneurship } \\
\text { Index (2015) }\end{array}$ & $\begin{array}{c}\text { Gender } \\
\text { Equality } \\
\text { Index (2012) }\end{array}$ & $\begin{array}{c}\text { Economic } \\
\text { Power } \\
\text { Equality } \\
\text { Index (2012) }\end{array}$ \\
\hline UK & 30 & 70.6 & 58.0 & 24.2 \\
\hline Latvia & 40 & 56.6 & 46.9 & 42.4 \\
\hline Greece & 30 & 43.0 & 38.3 & 17.0 \\
\hline Romania & 29 & 49.4 & 33.7 & 22.2 \\
\hline Turkey & 15 & 39.3 & $\mathrm{~N} / \mathrm{A}$ & $\mathrm{N} / \mathrm{A}$ \\
\hline Ireland & 20 & 64.6 & 56.5 & 25.5 \\
\hline
\end{tabular}

Source: Compiled by the author using data from the Gender Equality Index (2012), the Statistics on Women Entrepreneurship in Europe (2012), and the Female Entrepreneurship Index (2015).

\section{Data analysis}

For this analysis, innovation was defined according to Baregheh et al. (2009, p. 1334) as "the multi-stage process whereby organizations transform ideas into new/improved products, service or processes, in order to advance, compete and differentiate themselves successfully in their marketplace". Thus, the innovation behavior of firms was operationalized using three questions contained in the GEM Adult Population Survey of 2012: 
- Operations innovation - "How long have the technologies or procedures required for this product of service been available?" (Likert scale - 'less than a year', 'between one to five years', 'longer than five years');

- Customer product innovation - "Do all, some, or none of your potential customers consider this product or service new and unfamiliar?" (Likert scale 'all', 'some', 'none will consider this new and unfamiliar');

- Industry product innovation - "Right now, are there many, few, or no other businesses offering the same products or services to your potential customers?" (Likert scale - 'many business competitors', 'few business competitors', 'no business competitors')

These three variables measuring innovation behavior were also aggregated in order to obtain a general innovation level for each firm, using a simple averaging of the three indexes.

\section{Research results}

As the results showed that, in general, female and male entrepreneurs adopt the same innovation behavior, we further analyzed the way in which female entrepreneurs innovate by taking into account the country effect. In Table 2, we present the results of the comparison between female start-up entrepreneurs across the six countries in terms of customer product innovation.

Table 2. Testing customer product innovation differences across countries for female start-up entrepreneurs - ANOVA results

\begin{tabular}{|l|r|r|r|r|c|}
\hline & Sum of Squares & \multicolumn{1}{c|}{ df } & Mean Square & F & Sig. \\
\hline Between Groups & 16.908 & 5 & 3.382 & 6.805 & 0.000 \\
\hline Within Groups & 116.275 & 234 & 0,497 & & \\
\hline Total & 133.183 & 239 & & & \\
\hline
\end{tabular}

Source: Author's own research results.

The results of the one-way ANOVA comparison between countries showed that there is a significant difference between the countries in our sample so we continued with the post-hoc analysis using Tukey's test, assuming there is an equal variance between groups and the results are presented in Table 3.

Table 3. Testing customer product innovation differences across countries for female start-up entrepreneurs - multiple comparisons results

\begin{tabular}{|l|l|c|c|c|}
\hline \multirow{3}{*}{ (I) Country } & (J) Country & Mean Difference (I-J) & Std. Error & Sig. \\
\hline \multirow{4}{*}{ Greece } & Romania & 0.257 & 0.198 & 0.784 \\
\cline { 2 - 5 } & United Kingdom & -0.345 & 0.200 & 0.514 \\
\cline { 2 - 5 } & Turkey & 0.389 & 0.185 & 0.290 \\
\cline { 2 - 5 } & Ireland & -0.145 & 0.205 & 0.981 \\
\cline { 2 - 5 } & Latvia & -0.171 & 0.179 & 0.930 \\
\hline \multirow{5}{*}{ Romania } & Greece & -0.257 & 0.198 & 0.784 \\
\cline { 2 - 5 } & United Kingdom & $-0.603^{*}$ & 0.171 & 0.007 \\
\cline { 2 - 5 } & Turkey & 0.132 & 0.154 & 0.956 \\
\cline { 2 - 5 } & Ireland & -0.402 & 0.177 & 0.210 \\
\cline { 2 - 5 } & Latvia & $-0.429^{*}$ & 0.146 & 0.042 \\
\hline United Kingdom & Greece & 0.345 & & 0.514 \\
\hline
\end{tabular}




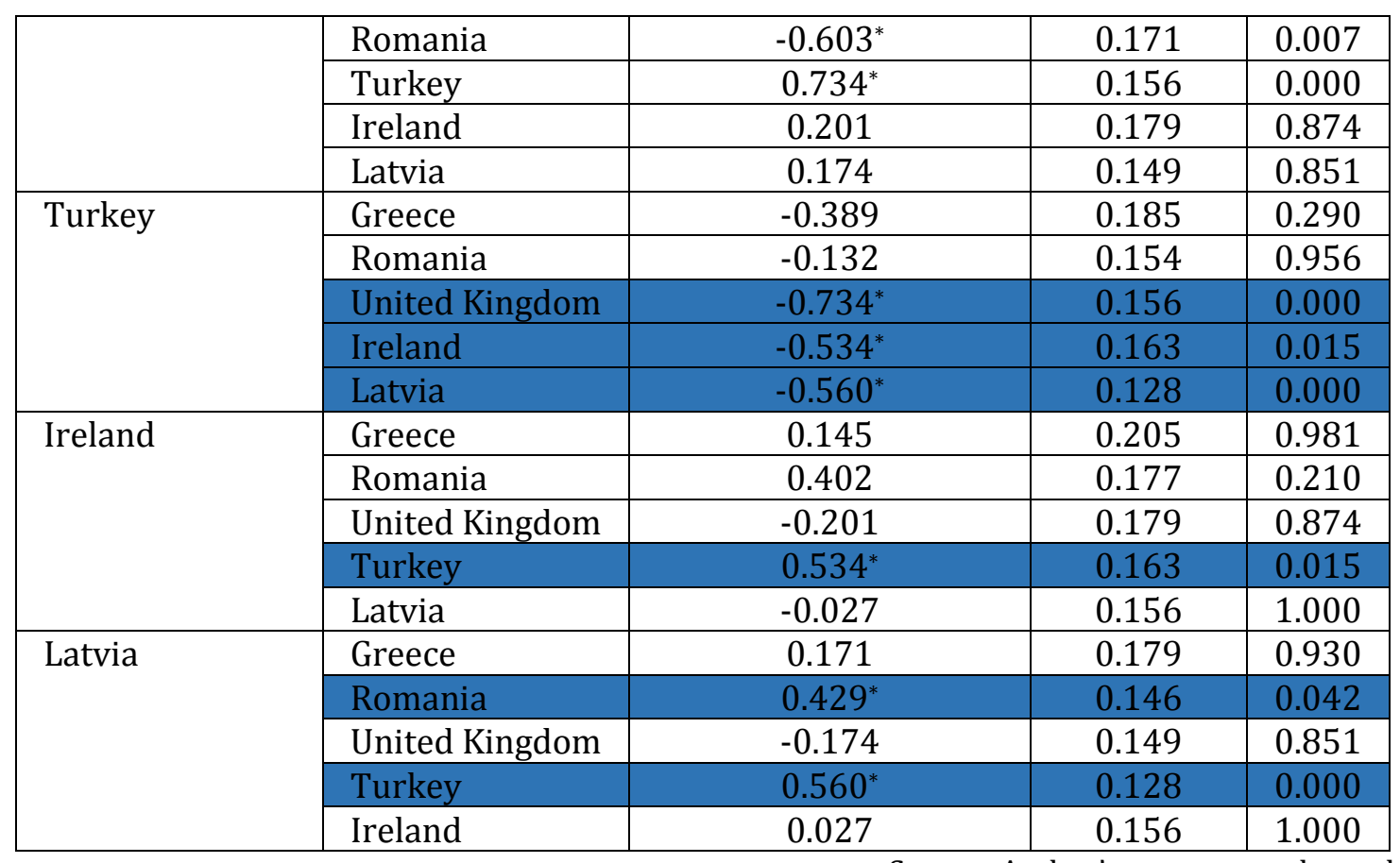

In terms of customer product innovation, the post-hoc analysis identified the presence of differences between the sample of female start-up entrepreneurs in Turkey and the female start-up entrepreneurs from the United Kingdom, Latvia, and Ireland, and between the sample of female start-up entrepreneurs from Romania and the female start-up entrepreneurs from the United Kingdom and Latvia. On average, Turkish female start-up entrepreneurs reported lower levels of customer product innovation than similar entrepreneurs from United Kingdom, Latvia and Ireland, while Romanian female start-up entrepreneurs reported lower levels that their counterparts in United Kingdom and Latvia.

We also performed a country comparison for female start-up entrepreneurs in terms of the level of industry product innovation and the ANOVA test showed significant differences between the groups, as presented in Table 4.

Table 4. Testing industry product innovation differences across countries for female start-up entrepreneurs - ANOVA results

\begin{tabular}{|l|r|r|r|r|c|}
\hline & Sum of Squares & \multicolumn{1}{c|}{ df } & Mean Square & F & Sig. \\
\hline Between Groups & 6.725 & 5 & 1.345 & 3.156 & 0.009 \\
\hline Within Groups & 104.422 & 245 & 0.426 & & \\
\hline Total & 111.147 & 250 & & & \\
\hline
\end{tabular}

Source: Author's own research results.

The results of the post-hoc analysis presented in Table 5 show that Romanian female start-up entrepreneurs report lower levels of industry product innovation than their English counterparts and that the same is true for Turkish female start-up entrepreneurs. For the rest of the countries, all of the differences were not statistically significant.

Table 5. Testing industry product innovation differences across countries - female start-up entrepreneurs - multiple comparisons results (Tukey HSD) 


\begin{tabular}{|c|c|c|c|c|}
\hline (I) Country & (J) Country & Mean Difference (I-J) & Std. Error & Sig. \\
\hline \multirow[t]{5}{*}{ Greece } & Romania & -0.008 & 0.177 & 1.000 \\
\hline & United Kingdom & -0.421 & 0.183 & 0.197 \\
\hline & Turkey & 0.060 & 0.172 & 0.999 \\
\hline & Ireland & -0.289 & 0.187 & 0.637 \\
\hline & Latvia & -0.056 & 0.165 & 0.999 \\
\hline \multirow[t]{5}{*}{ Romania } & Greece & 0.008 & 0.177 & 1.000 \\
\hline & United Kingdom & -0.413 & 0.149 & 0.064 \\
\hline & Turkey & 0.068 & 0.135 & 0.996 \\
\hline & Ireland & -0.281 & 0.154 & 0.452 \\
\hline & Latvia & -0.047 & 0.126 & 0.999 \\
\hline \multirow[t]{5}{*}{ United Kingdom } & Greece & 0.421 & 0.183 & 0.197 \\
\hline & Romania & 0.413 & 0.149 & 0.064 \\
\hline & Turkey & $0.481^{*}$ & 0.143 & 0.012 \\
\hline & Ireland & 0.133 & 0.161 & 0.963 \\
\hline & Latvia & 0.366 & 0.135 & 0.076 \\
\hline \multirow[t]{5}{*}{ Turkey } & Greece & -0.060 & 0.172 & 0.999 \\
\hline & Romania & -0.068 & 0.135 & 0.996 \\
\hline & United Kingdom & $-0.481^{*}$ & 0.143 & 0.012 \\
\hline & Ireland & -0.349 & 0.149 & 0.181 \\
\hline & Latvia & -0.115 & 0.120 & 0.929 \\
\hline \multirow[t]{5}{*}{ Ireland } & Greece & 0.289 & 0.187 & 0.637 \\
\hline & Romania & 0.281 & 0.154 & 0.452 \\
\hline & United Kingdom & -0.133 & 0.161 & 0.963 \\
\hline & Turkey & 0.349 & 0.149 & 0.181 \\
\hline & Latvia & 0.233 & 0.141 & 0.561 \\
\hline \multirow[t]{5}{*}{ Latvia } & Greece & 0.056 & 0.165 & 0.999 \\
\hline & Romania & 0.047 & 0.126 & 0.999 \\
\hline & United Kingdom & -0.366 & 0.135 & 0.076 \\
\hline & Turkey & 0.115 & -0.120 & 0.929 \\
\hline & Ireland & -0.233 & 0.141 & 0.561 \\
\hline
\end{tabular}

Source: Author's own research results.

Moreover, in what regards the country effect on female startup entrepreneurs' operations innovation level, the statistical analysis showed no significant differences between countries (see Table 6), which means that the adoption rate of new technologies is similar for the women start-up entrepreneurs in the six countries included in our sample.

Table 6. Testing operations innovation differences across countries for female start-up entrepreneurs - ANOVA results

\begin{tabular}{|l|r|r|r|r|c|}
\hline & Sum of Squares & \multicolumn{1}{c|}{ df } & Mean Square & F & Sig. \\
\hline Between Groups & 4.201 & 5 & 0.840 & 2.112 & 0.065 \\
\hline Within Groups & 93.094 & 234 & 0.398 & & \\
\hline Total & 97.296 & 239 & & & \\
\hline
\end{tabular}

Source: Author's own research results. 
Next we investigated the country differences for established female business owners, starting with the country effect on the level of customer product innovation. The results of the ANOVA test showed significant differences between countries, as shown in Table 7.

Table 7. Testing customer product innovation differences across countries for female established entrepreneurs - ANOVA results

\begin{tabular}{|l|r|r|r|r|c|}
\hline & Sum of Squares & \multicolumn{1}{c|}{ df } & Mean Square & F & Sig. \\
\hline Between Groups & 17.338 & 5 & 3.468 & 8.314 & 0.000 \\
\hline Within Groups & 169.330 & 406 & 0.417 & & \\
\hline Total & 186.667 & 411 & & & \\
\hline
\end{tabular}

Source: Author's own research results.

As the results of the one-way ANOVA comparison between countries showed that there is a significant difference between the countries in our sample, we continued with the post-hoc analysis using Tukey's test, assuming there is an equal variance between groups (see Table 8).

Table 8. Testing customer product innovation differences across countries - established female entrepreneurs - multiple comparisons results (Tukey HSD)

\begin{tabular}{|c|c|c|c|c|}
\hline (I) Country & (J) Country & Mean Difference (I-J) & Std. Error & Sig. \\
\hline \multirow{5}{*}{ Greece } & Romania & 0.240 & 0.132 & 0.459 \\
\hline & United Kingdom & -0.064 & 0.108 & 0.992 \\
\hline & Turkey & $0.524^{*}$ & 0.104 & 0.000 \\
\hline & Ireland & -0.073 & 0.097 & 0.976 \\
\hline & Latvia & 0.127 & 0.098 & 0.788 \\
\hline \multirow[t]{5}{*}{ Romania } & Greece & -0.240 & 0.132 & 0.459 \\
\hline & United Kingdom & -0.304 & 0.142 & 0.270 \\
\hline & Turkey & 0.284 & 0.139 & 0.325 \\
\hline & Ireland & -0.313 & 0.134 & 0.185 \\
\hline & Latvia & -0.112 & 0.135 & 0.961 \\
\hline \multirow[t]{5}{*}{ United Kingdom } & Greece & 0.064 & 0.108 & 0.992 \\
\hline & Romania & 0.304 & 0.142 & 0.270 \\
\hline & Turkey & $0.588^{*}$ & 0.117 & 0.000 \\
\hline & Ireland & -0.009 & 0.110 & 1.000 \\
\hline & Latvia & 0.191 & 0.111 & 0.520 \\
\hline \multirow[t]{5}{*}{ Turkey } & Greece & $-0.524^{*}$ & 0.104 & 0.000 \\
\hline & Romania & -0.284 & 0.139 & 0.325 \\
\hline & United Kingdom & $-0.588^{*}$ & 0.117 & 0.000 \\
\hline & Ireland & $-0.596^{*}$ & 0.107 & 0.000 \\
\hline & Latvia & $-0.396^{*}$ & 0.108 & 0.004 \\
\hline \multirow[t]{5}{*}{ Ireland } & Greece & 0.073 & 0.097 & 0.976 \\
\hline & Romania & 0.313 & 0.134 & 0.185 \\
\hline & United Kingdom & 0.009 & 0.110 & 1.000 \\
\hline & Turkey & $0.596^{*}$ & 0.107 & 0.000 \\
\hline & Latvia & 0.200 & 0.101 & 0.354 \\
\hline \multirow[t]{2}{*}{ Latvia } & Greece & -0.127 & 0.098 & 0.788 \\
\hline & Romania & 0.112 & 0.135 & 0.961 \\
\hline
\end{tabular}




\begin{tabular}{|l|l|l|l|l|}
\hline & United Kingdom & -0.191 & 0.111 & 0.520 \\
\cline { 2 - 5 } & Turkey & $0.396^{*}$ & 0.108 & 0.004 \\
\cline { 2 - 5 } & Ireland & -0.200 & 0.101 & 0.354 \\
\hline
\end{tabular}

Source: Author's own research results.

The analysis showed significant differences between female established entrepreneurs from Turkey, on the one hand, and, on the other hand, female established entrepreneurs in four other countries: Latvia, Ireland, Greece and United Kingdom in what regards the level of customer product innovation: Turkish female established entrepreneurs reported, on average, lower levels of customer product innovation than their counterparts from Ireland, United Kingdom, Latvia and Greece. However, in terms of industry product innovation, there were no differences between countries as the ANOVA analysis results presented in Table 9 show.

Table 9. Testing industry product innovation differences across countries for established female entrepreneurs - ANOVA results

\begin{tabular}{|l|r|r|r|r|c|}
\hline & Sum of Squares & \multicolumn{1}{c|}{ df } & Mean Square & F & Sig. \\
\hline Between Groups & 1.167 & 5 & 0.233 & 0.648 & 0.663 \\
\hline Within Groups & 148.742 & 413 & 0.360 & & \\
\hline Total & 149.909 & 418 & & & \\
\hline
\end{tabular}

Source: Author's own research results.

The last test was performed in order to see if there were differences in the level of operations innovation between the female-led business from the six countries included in the sample. The ANOVA test results (see Table 10) showed there were significant differences between the groups and thus we proceeded with the post-hoc analysis.

Table 10. Testing operations innovation differences across countries for established female entrepreneurs - ANOVA results

\begin{tabular}{|l|r|r|r|r|c|}
\hline & Sum of Squares & \multicolumn{1}{c|}{ df } & Mean Square & F & Sig. \\
\hline Between Groups & 10.139 & 5 & 2.028 & 8.474 & 0.000 \\
\hline Within Groups & 95.959 & 401 & 0.239 & & \\
\hline Total & 106.098 & 406 & & & \\
\hline
\end{tabular}

Source: Author's own research results.

Table 11. Testing operations innovation differences across countries - established female entrepreneurs - multiple comparisons results (Tukey HSD)

\begin{tabular}{|l|l|l|l|l|}
\hline \multirow{4}{*}{ (I) Country } & (J) Country & Mean Difference (I-J) & Std. Error & \multirow{2}{*}{ Sig. } \\
& & & & \\
\hline \multirow{5}{*}{ Greece } & Romania & $0.439^{*}$ & 0.099 & 0.000 \\
\cline { 2 - 5 } & United Kingdom & 0.023 & 0.082 & 1.000 \\
\cline { 2 - 5 } & Turkey & -0.113 & 0.080 & 0.722 \\
\cline { 2 - 5 } & Ireland & -0.136 & 0.074 & 0.443 \\
\cline { 2 - 5 } & Latvia & -0.158 & 0.075 & 0.280 \\
\hline \multirow{5}{*}{ Romania } & Greece & $-0.439^{*}$ & 0.099 & 0.000 \\
\cline { 2 - 5 } & United Kingdom & $-0.416^{*}$ & 0.107 & 0.002 \\
\cline { 2 - 5 } & Turkey & $-0.552^{*}$ & 0.105 & 0.000 \\
\cline { 2 - 5 } & Ireland & $-0.575^{*}$ & 0.101 & 0.000 \\
\cline { 2 - 5 } & Latvia & $-0.597^{*}$ & 0.101 & 0.000 \\
\hline United Kingdom & Greece & -0.023 & 0.082 & 1.000 \\
\cline { 2 - 5 } & Romania & $0.416^{*}$ & 0.107 & 0.002 \\
\hline \multirow{2}{*}{} & & & & \\
\hline
\end{tabular}




\begin{tabular}{|l|l|c|c|c|}
\hline \multirow{5}{*}{ Turkey } & Turkey & -0.136 & 0.090 & 0.658 \\
\cline { 2 - 5 } & Ireland & -0.159 & 0.084 & 0.415 \\
\cline { 2 - 5 } & Latvia & -0.181 & 0.085 & 0.273 \\
\hline \multirow{5}{*}{ Ireland } & Greece & 0.113 & 0.080 & 0.722 \\
\cline { 2 - 5 } & Romania & $0.552^{*}$ & 0.105 & 0.000 \\
\cline { 2 - 5 } & United Kingdom & 0.136 & 0.090 & 0.658 \\
\cline { 2 - 5 } & Ireland & -0.023 & 0.082 & 1.000 \\
\cline { 2 - 5 } & Latvia & -0.045 & 0.083 & 0.994 \\
\hline \multirow{5}{*}{ Latvia } & Greece & 0.136 & 0.074 & 0.443 \\
\cline { 2 - 5 } & Romania & $0.575^{*}$ & 0.101 & 0.000 \\
\cline { 2 - 5 } & United Kingdom & 0.159 & 0.084 &, 415 \\
\cline { 2 - 5 } & Turkey & 0.023 & 0.082 & 1.000 \\
\cline { 2 - 5 } & Latvia & -0.022 & 0.077 & 1.000 \\
\cline { 2 - 5 } & Greece & 0.158 & 0.075 & 0.280 \\
\cline { 2 - 5 } & Romania & $0.597^{*}$ & 0.101 & 0.000 \\
\cline { 2 - 5 } & United Kingdom & 0.181 & 0.085 & 0.273 \\
\cline { 2 - 5 } & Turkey & 0.045 & 0.083 & 0.994 \\
\cline { 2 - 5 } & Ireland & 0.022 & 0.077 & 1.000 \\
\hline
\end{tabular}

The post-hoc analysis in Table 11 revealed that there were differences only between the level of technology adoption of female-led businesses from Romania and the female-led business in the rest of the five countries included in the sample: Romanian women established entrepreneurs consistently report using new technologies in their operations less than the other female established entrepreneurs.

By comparing the results obtained for both female start-up entrepreneurs' and established female business owners, we conclude that there is partial evidence to support our hypotheses as follows:

RH1: There are differences between female entrepreneurs generated by country effects in terms of the level of customer product innovation.

The statistical tests showed there were differences between female established entrepreneurs in Turkey and their counterparts in the other five countries included in the sample and similar results were found also found for Turkish female start-up entrepreneurs, which, on average, reported lower levels of customer product innovation than similar entrepreneurs from United Kingdom, Latvia and Ireland. The analysis also showed that Romanian female start-up entrepreneurs reported lower levels of customer product innovation that their counterparts in United Kingdom and Latvia. Thus, there is evidence that there are significant differences between Turkey and Romania and the other countries, and thus we conclude that hypothesis RH1 is partially supported.

RH2: There are differences between female entrepreneurs generated by country effects in terms of the level of industry product innovation.

The only difference between countries related to industry product innovation was found between female start-up entrepreneurs from United Kingdom, which, on average, reported more frequently the introduction of products that were also sold by few or no competitors than their counterparts from Romania and Turkey. Thus, the evidence supporting RH2 is weak and we accept it only partially.

RH3: There are differences between female entrepreneurs generated by country effects in terms of the level of operations innovation. 
The statistical tests have shown significant differences between Romanian female established entrepreneurs and their counterparts in all the other five countries, but when looking at the sample of female start-up entrepreneurs, we did not identify any significant differences, and thus conclude that there is only partial support for RH3.

\section{Discussions and conclusions}

Our analysis showed that there are consistent differences between the innovation behavior of female entrepreneurs from Turkey and Romania and the female entrepreneurs from the other countries included in the sample, United Kingdom, Ireland, Latvia and Greece. However, no clear patterns emerged in regards to the influence of the indicators we used in order to characterize the country's landscape in terms of female entrepreneurship: the percentage of female entrepreneurs, the public support for high-growth female entrepreneurship, and the gender and economic power equality indices.

Romanian female established entrepreneurs reported lower levels of operations innovation than their counterparts in all the other five countries. Moreover, Romanian female start-up entrepreneurs reported lower levels of customer product innovation and industry product innovation than their counterparts in United Kingdom, and lower levels of customer product innovation than Latvian female startup entrepreneurs. Out of the six countries included in the sample, Romania has a rather high percentage of female entrepreneurs, but the country offers less support for high-growth female entrepreneurs than the other countries except for Greece and Turkey and also registers lower levels of gender equality than all the other countries (for Turkey there is no available data).

Turkish female established entrepreneurs reported lower levels of customer product innovation than their counterparts from the other five countries included in the sample and similar results were found also found for Turkish female start-up entrepreneurs, which, on average, reported lower levels of customer product innovation than similar entrepreneurs from United Kingdom, Latvia and Ireland. Moreover, Turkish female start-up entrepreneurs reported lower levels of industry product innovation than their counterparts in United Kingdom. Turkey has a very low percentage of female entrepreneurs (15\% in 2012) and it offers less support for highgrowth female entrepreneurship than the other countries.

Consequently, we can conclude that we have obtained partial confirmation of the fact that there are country-related factors which have an impact on the level and type of innovation behavior displayed by female led-businesses for the countries we included in our analysis, but that the indicators we used (percentage of female entrepreneurs, support for high-growth female entrepreneurship and gender equality) are not good predictors of the level of innovation encountered in women led-businesses. We also conclude that further research into the topic of innovation in female-led businesses should also try to incorporate more aspects related to the cultural environment which affect both women and men entrepreneurs such as fear of failure and the ability to recover from past mistakes, the public image of entrepreneurs and how the entrepreneurial role fits within the other roles played by 
men and women (Cantaragiu and Hadad, 2014). Thus, further analysis is required in order to identify the support factors for female entrepreneurship and innovation, and, as our results showed, it appears that for a better understanding of these factors it is more appropriate to look at industry sectors separately rather than treating them as if they were homogeneous.

\section{References}

Ahl, H. (2006), "Why research on women entrepreneurs needs new directions", Entrepreneurship Theory \& Practice, Vol. 30, No. 5, pp. 595-621.

Akulava, M. (2015), “Does gender matter for the innovativeness of SMEs?", FREE Policy Brief Series, available online at: freepolicybriefs.org/2015/10/05/does-gender-matter-forthe-innovativeness-of-smes (accessed July 27, 2016).

Belghiti-Mahut, S., Lafont, A.L. and Yousfi, O. (2016), "Gender gap in innovation: a confused link?", Journal of Innovation Economics \& Management, Vol. 1, No. 19, pp. 159-177.

Blake, M.K. and Hanson, S. (2005), "Rethinking innovation: context and gender", Environment and Planning, Vol. 37, No. 4, pp. 681-701.

Bobera, D. and Lekovic, B. (2013), "Barriers to innovation in Ap Vojvodina: analysis of data and research findings from the aspect of age and gender", Interdisciplinary Management Research, Vol. 9, pp. 57-66.

Calás, M.B., Smircich, L. and Bourne, K.A. (2009), "Extending the boundaries: Reframing "entrepreneurship as social change" through feminist perspectives", Academy of Management Review, Vol. 34, No. 3, pp. 552-569.

Cantaragiu, R. and Hadad, S. (2014), "The importance of play in overcoming fears of entrepreneurial failure", Proceedings of the 14th European Conference on Knowledge Management, Kaunas University of Technology, September 6, 2013, Academic Conferences and Publishing International Limited, pp. 833-843.

Cirera, X. and Qasim, Q. (2014), "Supporting growth-oriented women entrepreneurs: A review of the evidence and key challenges", Innovation, Technology \& Entrepreneurship Policy Note, Vol. September 2014, No. 5, World Bank Group.

Fagerberg, J., Mowery, D.C. and Nelson, R.R. (2005), The Oxford Handbook of Innovation, Oxford University Press, Oxford.

Filculescu, A. and Cantaragiu, R. (2012), "Innovation in the creative industries: Case study of an event planning company", Annals of the Faculty of Economics, Vol. 1, No. 1, pp. 640649.

Hughes, K.D., Jennings, J.E., Brush, C., Carter, S. and Welter, F. (2012), “Extending women's entrepreneurship research in new directions", Entrepreneurship Theory \& Practice, Vol. 36, No. 3, pp. 429-442.

Huysentruty, M. (2014), "Women's social entrepreneurship and innovation", OECD Local Economic and Employment Development (LEED) Working papers, 2014/1, OECD Publishing.

Ighomereho, O.S., Agbalajobi, T.D. and Edegwa, K.S. (2013), "Gender influences on access to innovation resources in Nigeria", International Journal of Humanities and Social Science, Vol. 3, No. 1, pp. 216-227.

Jensen, K.W. (2014), “Gendering of firm's collaboration networks and innovation: A global study with a focus on China, Japan and South Korea", International Journal of Entrepreneurship and Small Business, Vol. 23, No. 1-2, pp. 213-234.

Kalleberg, A. and Leitch, K. (1991), "Gender and organizational performance: Determinants of small business survival and success", Academy of Management Journal, Vol. 34, No. 1, pp. 136-161. 
MMCKS Marvel, M.R. and Lee, I.H.I. (2011), "Gender and the innovation activity of entrepreneurs: A multilevel analysis", Frontiers of Entrepreneurship Research, Vol. 31, No. 8, pp. 283296.

Polkowska, D. (2013), "Women scientists in the leaking pipeline: Barriers to the commercialization of scientific knowledge by women", Journal of Technology Management \& Innovation, Vol. 8, No. 2, pp. 156-165.

Ranga, M. and Etzkowitz, H. (2010), "Athena in the world of techne: The gender dimension of technology, innovation and entrepreneurship", Journal of Technology Management \& Innovation, Vol. 5, No, 1, pp. 1-12.

Runyan, C. R., Huddleston, P. and Swinney, J. (2006), “Entrepreneurial orientation and social capital as small firm strategies: a case study of gender differences from resourcesbased view", Entrepreneurship Management, Vol. 2, pp. 455 - 477.

Serviere-Munoz, L. and Saran, A. (2012), "Market orientation, innovation and dynamism from an ownership and gender approach: Evidence for Mexico", International Journal of Management and Marketing Research, Vol. 5, No. 2, pp. 1-8.

Sullivan, D.M. and Meek, W.R. (2012), "Gender and entrepreneurship: A review and process model”, Journal of Managerial Psychology, Vol. 27, No. 5, pp. 428-458.

VanderBrug, J. (2013), The global rise of female entrepreneurs, Harvard Business Review, September 4, 2013, available online at: hbr.org/2013/09/global-rise-of-femaleentrepreneurs (accessed July 12, 2016).

Watking, K., Ozkazanc-Pan, B, Muntean, C.S. and Motoyama, Y. (2015), "Innovating the innovation community: Strategies to include women entrepreneurs", Ewing Marion Kauffman Foundation, February 11, 2015, available online at: www.kauffman.org/blogs/growthology/2015/11/innovating-the-innovationcommunity-strategies-to-include-women-entrepreneurs (accessed July 12, 2016).

Zapalska, A. (1997), "A profile of woman entrepreneurs and enterprises in Poland", Journal of Small Business Management, Vol. 35, No. 4, pp. 76-82. 